SGW-47024

Revision 0

\title{
Standards Controlling Air Emissions for the Soil Desiccation Pilot Test
}

Prepared for the U.S. Department of Energy

Assistant Secretary for Environmental Management

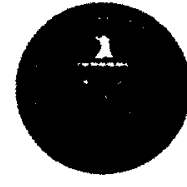

U.S. DEPARTMENT OF a $=$ C

Richland Operations Office

P.O. Box 550

Richland, Washington 99352

Approved for Public Release;

Further Dissemination Unlimited 


\section{Standards Controlling Air Emissions for the Soil Desiccation Pilot Test}

Date Published

September 2010

Prepared for the U.S. Department of Energy

Assistant Secretary for Environmental Management

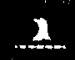

U.S. DEPARTMENT OF ENERGY

P.O. Box 550

Richland, Washington 99352
Richland Operations Office

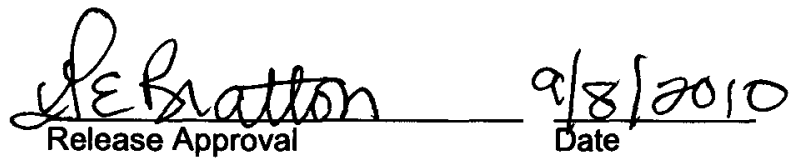

Approved for Public Release;

Further Dissemination Unlimited 
TRADEMARK DISCLAIMER

Reference herein to any specific commercial product, process,

or service by trade name, trademark, manufacturer, or

otherwise, does not necessarily constitute or imply its

endorsement, recommendation, or favoring by the United

States Government or any agency thereof or its contractors or

subcontractors.

This report has been reproduced from the best available copy. 


\title{
Approval Page
}

Title

SGW-47024, Standards Controlling Air Emissions for the Soil Desiccation Pilot Test

Approval

\author{
B. L. Charboneau
}

U. S. Department of Energy, Richland Operations Office

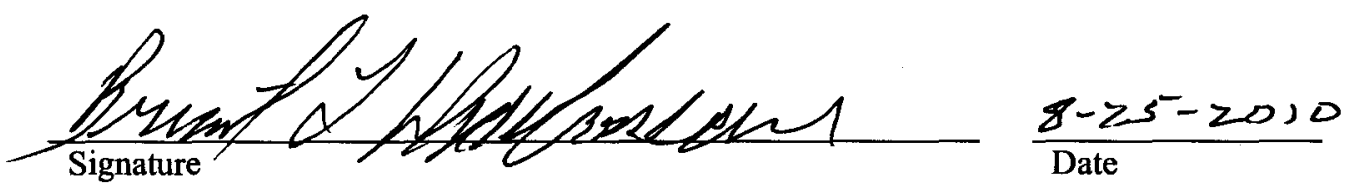

\section{Concurrence R. A. Lobos}

U. S. Environmental Protection Agency

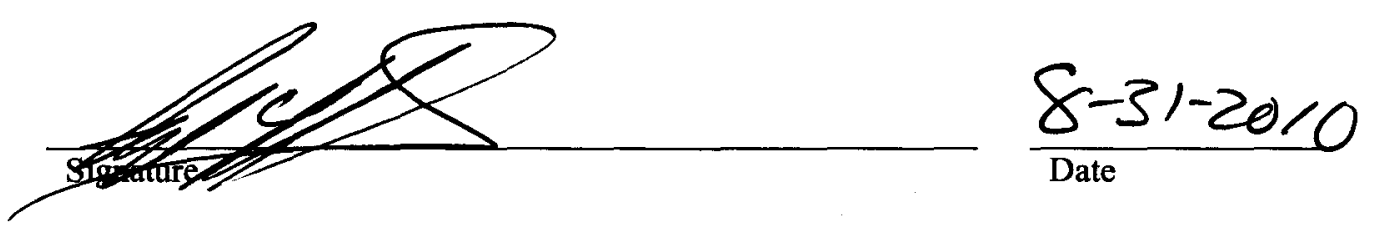


SGW-47024, REV. 0 


\section{Contents}

1 Introduction 1

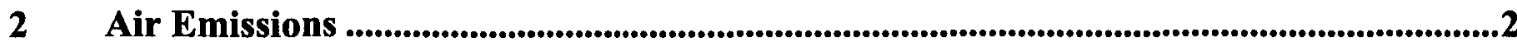

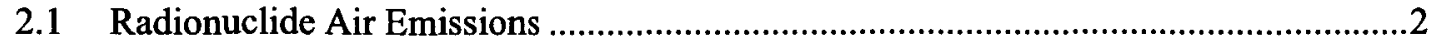

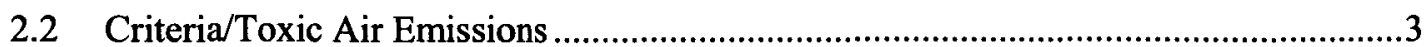

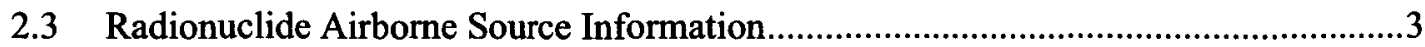

2.4 Criteria/Toxic Airborne Source Information .........................................................

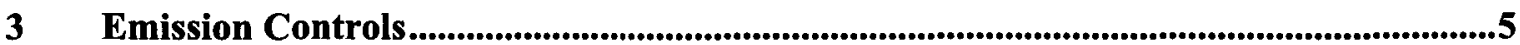

4 Monitoring.....................................................................................................................................5

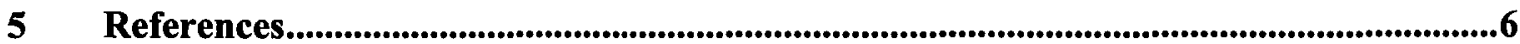

Figures

Figure 1. Schematic of Soil Desiccation Pilot Test . .1

\section{Terms}

$\begin{array}{ll}\text { APQ } & \text { Annual Possession Quantity } \\ \text { CERCLA } & \begin{array}{l}\text { Comprehensive Environmental Response, Compensation, and Liability Act of } \\ 1980 \\ \text { EDE }\end{array} \\ \text { EPA } & \text { U.S. Environmental Protection Agency } \\ \text { ERDF } & \text { Environmental Restoration Disposal Facility } \\ \text { MEI } & \text { maximally exposed individual } \\ \text { MPR } & \text { maximum public receptor } \\ \text { PTE } & \text { potential-to-emit } \\ \text { scfm } & \text { standard cubic feet per minute } \\ \text { SDPT } & \text { soil desiccation pilot test }\end{array}$


SGW-47024, REV. 0 


\section{Introduction}

This air emissions document supports implementation of the Treatability Test Plan for Soil Desiccation as outlined in the Deep Vadose Zone Treatability Test Plan for the Hanford Central Plateau (DOE/RL-2007-56). Treatability testing supports evaluation of remedial technologies for technetium-99 (Tc-99) contamination in the vadose zone at sites such as the BC Cribs and Trenches. Soil desiccation has been selected as the first technology for testing because it has been recommended as a promising technology in previous Hanford Site technology evaluations and because testing of soil desiccation will provide useful information to enhance evaluation of other technologies, in particular gas-phase remediation technologies. A soil desiccation pilot test (SDPT) will evaluate the desiccation process (e.g., how the targeted interval is dried) and the long-term performance for mitigation of contaminant transport. The SDPT will dry out a moist zone contaminated by Tc- 99 and nitrate that has been detected at Well 299-E13-62 (Borehole C5923). This air emissions document applies to the activities to be completed to conduct the SDPT in the 200-BC-1 operable unit located in the 200 East Area of the Hanford Site.

Well 299-E13-62 is planned to be used as an injection well. This well is located between and approximately equidistant from cribs 216-B-16, 216-B-17, 216-B-18. and 216-B-19. Nitrogen gas will be pumped at approximately $300 \mathrm{ft}^{3} / \mathrm{min}$ into the 299-E13-62 injection well, located approximately $12 \mathrm{~m}$ (39 ft) away from extraction well 299-E13-65. The soil gas extraction rate will be approximately $150 \mathrm{ft}^{3} / \mathrm{min}$. The SDPT will be conducted continuously over a period of approximately six months. The purpose of the test is to evaluate soil desiccation as a potential remedy for protecting groundwater. A conceptual depiction is provided in Figure 1.

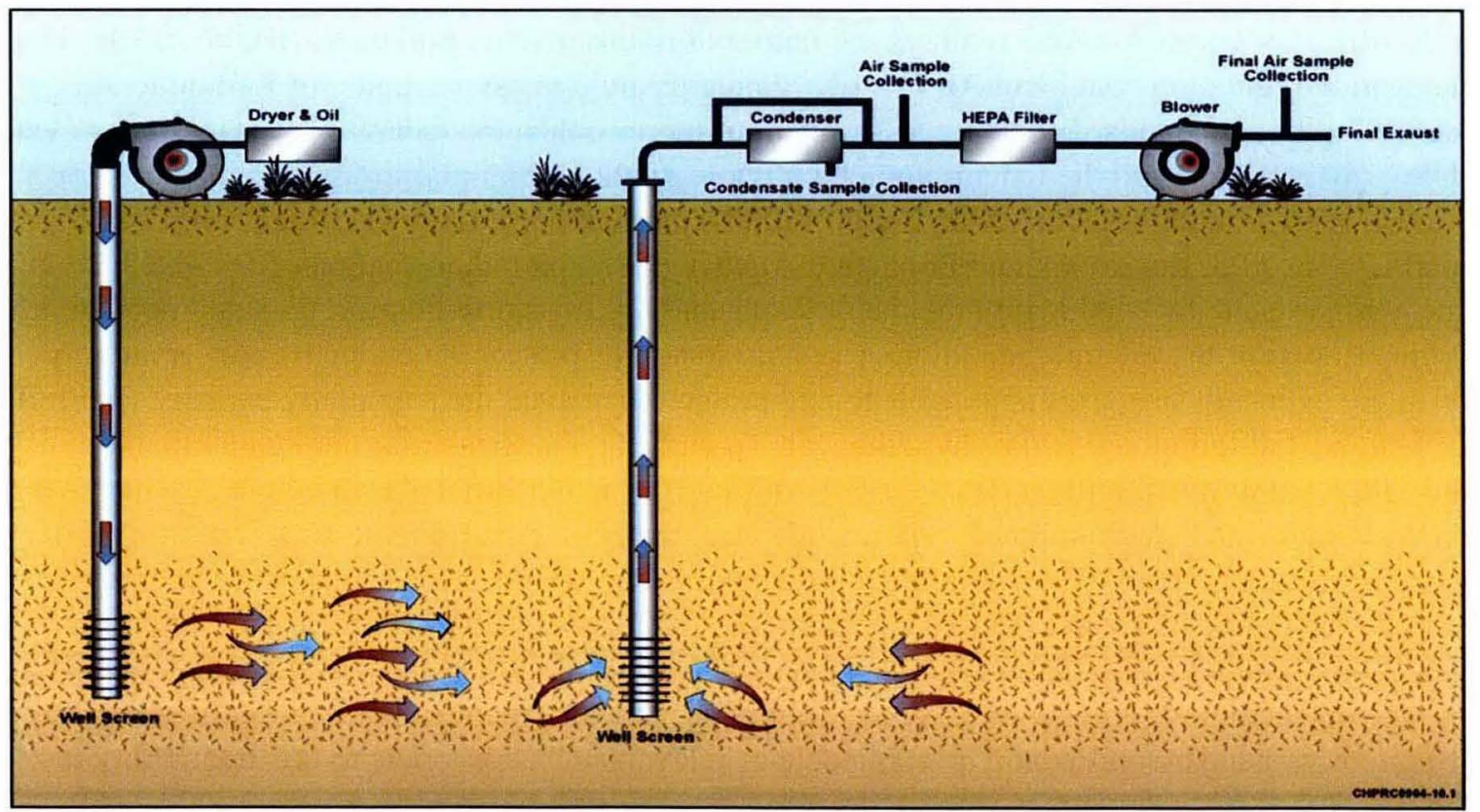

Figure 1. Schematic of Soil Desiccation Pilot Test

The soil desiccation process will physically dry, or evaporate, some of the water from the moist zone of interest. As such, it is expected that Tc-99 and nitrate will remain with the water residual that is not removed, or remain as a salt bound to the soil particles. In addition, the SDPT will be conducted at lower extraction velocities to preclude pore water entrainment and thus, the extracted air effluent should be free of the contaminant residual present in the targeted moist zone. 
However, to conservatively bound the planned activity for potential radionuclide air emissions, it is assumed, hypothetically, that the Tc-99 does not remain in the zone of interest, but that it instead travels with the evaporated moisture to the extraction well and to the test equipment at the land surface. Thus, a release potential would exist from the planned point source (powered exhaust) for Tc-99 in the extracted moist air. In this hypothetical bounding case there would also be a potential for very minor fugitive emissions to occur due to nitrogen injection into the soil. The maximum value for Tc-99, measured in the contaminated moist zone, is used in calculating the release potential described in Section 2.3.

The desiccation mechanism will be evaporation.

Nitrate is neither a criteria pollutant nor a toxic air pollutant. It would remain nitrate as a salt adhered to sand and silt grains or as nitrate dissolved in the pore water. Nitrogen, an inert gas, will be injected into the ground during the test. Tracer gasses will also be injected near the beginning, middle, and the end of the test. The tracer gasses are sulfur hexafluoride, trichlorofluoromethane, and difluoromethane.

\section{Air Emissions}

The following sections address radionuclide and criteria/toxic air emissions. Comprehensive Environmental Response, Compensation, and Liability Act of 1980 (CERCLA) Section 121, requires remedial actions to meet the substantive requirements of other promulgated environmental regulations that are either applicable, or relevant and appropriate, to the planned remedial activities.

At the same time, the procedural and administrative aspects of those regulations, such as permitting requirements, do not apply to onsite CERCLA actions like this one.

\subsection{Radionuclide Air Emissions}

The "Washington Clean Air Act" requires regulation of radioactive air pollutants (RCW 70.94). The state implementing regulation "Ambient Air Quality Standards and Emission Limits for Radionuclides"

(WAC 173-480) sets standards that are as stringent or more so than the federal Clean Air Act of 1990 (42 USC 7401, et seq.) and the federal implementing regulation "National Emission Standards for Emissions of Radionuclides Other than Radon from Department of Energy Facilities" (40 CFR 61, Subpart H). The U.S. Environmental Protection Agency (EPA) partial delegation of the 40 CFR 61 authority to the State of Washington includes all substantive emissions monitoring, abatement, and reporting aspects of the federal regulation. The state standards protect the public by conservatively establishing exposure standards applicable to and protective of even the maximally exposed (public) individual, be that individual real or hypothetical. To that end, the standards address any member of the public, at the point of maximum annual air concentration in an unrestricted area where any member of the public may be located. All combined radionuclide airborne emissions from the U.S. Department of Energy Hanford Site "facility" are not to exceed amounts that would cause an exposure to any said member of the public of greater than $10 \mathrm{mrem} / \mathrm{yr}$ effective dose equivalent (EDE). The state implementing regulation "Radiation Protection-Air Emissions" (WAC 246-247), which adopts the WAC 173-480 standards and the 40 CFR 61, Subpart $H$ standard, requires verification of compliance with the $10 \mathrm{mrem} / \mathrm{yr}$ standard and would be applicable or relevant and appropriate to this treatability test action.

WAC 246-247 addresses potential radioactive airborne emissions from point sources and from fugitive or diffuse sources by requiring monitoring of such sources. For sources of fugitive/diffuse emissions, such monitoring requires physical measurement (i.e., sampling) of the effluent or ambient air and quality assurance measures to assure the precision, accuracy, and completeness of the environmental measurements. The substantive provisions of WAC 246-247 that require monitoring of radioactive 
airborne emissions and the related quality assurance would be applicable or relevant and appropriate to this treatability test action.

The above state implementing regulations further address control of radioactive airborne emissions where economically and technologically feasible ("Radiation Protection-Air Emissions," "General Standards," and associated definitions [WAC 246-247-040(3) and -040(4)].) To address the substantive aspect of these requirements, best or reasonably achievable control technology will be addressed by ensuring that applicable emission control technologies (those successfully operated in similar applications) will be used when economically and technologically feasible (i.e., based on cost/benefit).

\subsection{Criteria/Toxic Air Emissions}

Under "General Regulations for Air Pollution Sources" (WAC 173-400) and "Controls for New Sources of Toxic Air Pollutants" (WAC 173-460), requirements are established for the regulation of emissions of criteria/toxic air pollutants. The powered exhaust will be temporary, running continuously for approximately six months. Therefore, "Portable and Temporary Sources" (WAC 173-400-035) is applicable. Potential criteria/toxic emissions resulting from this investigative action could be gaseous and/or particulate matter. In accordance with "General Standards for Maximum Emissions" (WAC 173-400-040), reasonable precautions must be taken to prevent the release of air contaminants associated with point sources and fugitive emissions resulting from excavation, materials handling, or other operations. The use of treatment technologies for emissions of toxic air pollutants that would be subject to the substantive applicable requirements of WAC 173-460 and WAC 173-400 are not anticipated to be a part of this characterization action. Calculations provided in Section 2.4 show that maximum potential concentrations would be below regulatory thresholds.

Above-ground treatment of some waste encountered during this investigative action may be required to meet Environmental Restoration Disposal Facility (ERDF) waste acceptance criteria. In most cases, the type of treatment anticipated would consist of solidification/stabilization techniques such as macroencapsulation or grouting, and WAC 173-460 would not be considered an applicable or relevant and appropriate requirement. If treatment that is more aggressive is required that would result in the emission of regulated air pollutants, the substantive requirements of WAC 173-460-040 and WAC 173-460-060 would be evaluated to determine applicability.

\subsection{Radionuclide Airborne Source Information}

The potential-to-emit (PTE) is calculated using Method 1: Annual Possession Quantity, according to Calculating Potential-to-Emit Radiological Releases and Doses (DOE/RL-2006-29, Rev. 0). The radiological constituent of concern is Tc-99. The PTE calculation is based upon the following.

- Tc-99 in the vadose zone soil subject to release is held in the soil pore water. All soil pore water is at the maximum Tc-99 concentration of $2.21 \mathrm{E}+06 \mathrm{pCi} / \mathrm{L}$ observed in the test target region of extraction well 299-E13-65 (Characterization of the Soil Desiccation Pilot Test Site, DOE/RL-2009-119). The mechanism for partitioning soil pore water to the atmosphere is evaporation. As such, Tc-99 is expected to remain with residual soil moisture that is bound to the granular soil matrix. However, as a conservative bounding case, it is assumed that Tc-99 is transferred, unabated, with evaporated soil moisture to the atmosphere.

- A release fraction of $1 \mathrm{E}-03$ is used for a liquid physical state.

- Discharged soil air is assumed to be at 100 percent relative humidity at $17.2^{\circ} \mathrm{C}$. 
- Air at 100 percent relative humidity and $17.2^{\circ} \mathrm{C}$ is equivalent to $12.28 \mathrm{~g} \mathrm{H}_{2} \mathrm{O} / \mathrm{kg}$ air (http://www.lenntech.com/calculators/relative-humidity.htm). The extracted air temperature, $17.2{ }^{\circ} \mathrm{C}$, is assumed to be identical to the sediment temperature as measured during the characterization phase of the SDPT.

- No credit is taken for Tc-99 reduction by removal of soil moisture in the chiller/condensate system.

- No credit is taken for Tc-99 removal by high efficiency filtration.

- Assume all Tc-99 is Cesium-137 (Cs-137) plus progeny for dose calculation.

- Use the most conservative (highest) Cs-137 plus progeny unit dose conversion factor for releases from the 200 East Area to the maximum public receptor (MPR) as provided in DOE/RL-2006-29.

- The duration of active pump exhaust is assumed to be six months $(4,320 \mathrm{hr})$.

- Soil air extraction rate is assumed to be 300 standard cubic feet per minute (scfm).

- Volume of discharged air: $(300 \mathrm{scfm})(4,320 \mathrm{hr})(60 \mathrm{~min} / \mathrm{hr})=7.78 \mathrm{E}+07 \mathrm{scf}$ $(7.78 \mathrm{E}+07 \mathrm{scf})\left(0.0283 \mathrm{~m}^{3} / \mathrm{ft}^{3}\right)=2.20 \mathrm{E}+06 \mathrm{~m}^{3}$

- Mass of water discharged at 100 percent relative humidity: (volume of air discharged) $\left(\mathrm{g} \mathrm{H}_{2} \mathrm{O} / \mathrm{kg}\right.$ air @ 100 percent humidity) $\left(7.78 \mathrm{E}+07 \mathrm{ft}^{3} \times \mathrm{m}^{3} / 35.314 \mathrm{ft}^{3} \times 12.28 \mathrm{~g} \mathrm{H}_{2} \mathrm{O} / \mathrm{m}^{3}=2.71 \mathrm{E}+7 \mathrm{~g}\right.$

- Volume of discharged water: (mass of $\mathrm{H}_{2} \mathrm{O}$ in $\mathrm{g}$ )(density of $\mathrm{H}_{2} \mathrm{O}$ in $\mathrm{mL} / \mathrm{g}$ ) $(\mathrm{L} / 1,000 \mathrm{~mL}$ ) $(2.71 \mathrm{E}+07 \mathrm{~g})(1 \mathrm{~mL} / \mathrm{g})(1 \mathrm{~L} / 1,000 \mathrm{~mL})=2.71 \mathrm{E}+04 \mathrm{~L} \mathrm{H}_{2} \mathrm{O}$ - Annual Possession Quantity (APQ): (volume of water discharged in $\mathrm{L})(\mathrm{Tc}-99$ concentration in water in $\mathrm{pCi} / \mathrm{L}$ ) $(2.71 \mathrm{E}+04 \mathrm{~L})(2.21 \mathrm{E}+06 \mathrm{pCi} / \mathrm{L})=5.99 \mathrm{E}+10 \mathrm{pCi}=5.99 \mathrm{E}-02 \mathrm{Ci}$

- PTE Quantity:

(APQ)(Release Fraction for Liquid) $(5.99 \mathrm{E}-02 \mathrm{Ci} / \mathrm{yr})(1 \mathrm{E}-03)=5.99 \mathrm{E}-05 \mathrm{Ci} / \mathrm{yr}$

- Unabated beta/gamma dose as Cs-137 plus progeny:

(PTE Quantity)(Cs-137 plus progeny onsite maximally exposed individual (MEI) unit dose conversion factor $=$ dose to $\mathrm{MEI})$

$(5.99 \mathrm{E}-05 \mathrm{Ci} / \mathrm{yr})(2.7 \mathrm{E}-1 \mathrm{mrem}$ total $\mathrm{EDE}$ to the $\mathrm{MEI} / \mathrm{Ci})=1.62 \mathrm{E}-05 \mathrm{mrem} / \mathrm{yr}$ total EDE to the MEI

The distance to the Energy Northwest MPR is approximately $18,310 \mathrm{~m}(60,072 \mathrm{ft})$ east-southeast of the 200 East BC Cribs and Trenches Area. This is the nearest public location where the hypothetical MEI might be located. The dose per unit curie Cs- 137 plus progeny airborne release factor used (specific to the $\mathrm{BC}$ Cribs and Trenches location with an effective release height less than $40 \mathrm{~m}$ [131 ft] and the onsite MPR) was taken from Table 4-9 of DOE/RL-2006-29. The factors are based on approved modeling using the agency-approved model CAP- 88 PC, Version 2.0. The total unabated PTE to the MEI from the 
proposed deep vadose zone soil desiccation characterization test would result in $1.62 \mathrm{E}-05 \mathrm{mrem} / \mathrm{yr}$ total EDE.

\subsection{Criteria/Toxic Airborne Source Information}

There are no potential toxic air emissions. Two of the tracer gasses, trichlorofluoromethane and difluoromethane, are ozone-depleting substances that are regulated as criteria pollutants. As such, the emissions threshold is one ton per year for ozone depleting substances. The anticipated usage of the tracer gasses is 10 to 50 pounds per use. It is expected to inject the tracer gasses near the beginning, middle, and end of the treatability test. The upper bounding estimate for the two ozone depleting substances is:

- $\quad(50$ pounds)( 3 events $)(2$ ozone depleting substances $)=300$ pounds

This is less than the regulatory threshold of one ton per year.

\section{Emission Controls}

No emission controls are needed for criteria/toxic air emissions.

Based on analysis of the potential radionuclide airborne emissions and best available control technologies, the following controls have been selected for use during the investigative action.

- The above-ground air handling system will employ a chiller/condenser and upstream heater, as necessary, to remove a portion of the water vapor for the purposes of collecting samples, protecting the blower and filter, and reducing potential discharge of Tc-99 to the atmosphere.

- One stage of filtration incorporating high efficiency particulate air type filtration media will be in place to mitigate release of particulates associated with the airborne effluent.

\section{Monitoring}

No monitoring is needed for criteria/toxic air emissions.

Based on analysis of the unabated release potential for radionuclide airborne emissions, the emission unit has a potential-to-emit of less than $0.1 \mathrm{mrem} / \mathrm{yr}$ total EDE to the MEI (minor source). Specifically, the calculated unabated annual dose to the MEI for the deep vadose zone soil desiccation characterization test is $1.62 \mathrm{E}-5 \mathrm{mrem} / \mathrm{yr}$ total EDE to the MEI. This activity represents a minor source requiring periodic confirmatory measurement to verify low emissions. This measurement will be conducted during the pilot test by use of a standard vacuum sample pump for effluent sample extraction using a standard sample collection head with very high efficiency particulate sample filter. The sampled effluent will be withdrawn from the point of active pump exhaust at all times the pump exhaust is operating except during sample collection and minor maintenance periods. A low volume air sampler of equivalent design will also be placed at the point of active pump exhaust and be used at all times the system is in operation except during sample collection and maintenance periods.

Additional monitoring will be conducted and will consist of radiological surveys using hand-held instruments at the exhaust port at the end of each two weeks of operation. Beta/gamma surveys will be performed for all removable contamination field surveys. Contamination levels will be determined using a conservative representative gamma emitter, typically Cs-137 for beta/gamma.

The existing network of near facility monitors for the 200 East Area will be utilized to address any fugitive or diffuse radionuclide air emissions resulting from the proposed activity. EPA Region 10 Hanford Project Office will be informed in the event any air sample exceeds 10 percent of the 
concentration values listed in Table 2 of Appendix E in 40 CFR 61, as measured by any of the 200 East Area near facility ambient air monitors. In the context of as low as reasonably achievable and worker protection, the following actions would be required based on radiological monitoring.

- If contamination surveys in the ventilation exhaust port exceed $1,000 \mathrm{dpm} / 100 \mathrm{~cm}^{2}$ beta/gamma or $20 \mathrm{dpm} / 100 \mathrm{~cm}^{2}$ alpha, then secure work, secure ventilation, and investigate the source of the . contamination.

- If the low volume air sample results at the ventilation exhaust exceed 0.3 Derived Air Concentration after decay of naturally occurring radionuclides, then suspend work, secure ventilation, and investigate the source of the contamination.

\section{References}

40 CFR 61, "National Emission Standards for Hazardous Air Pollutants," Subpart H, "National Emission Standards for Emissions of Radionuclides Other Than Radon from Department of Energy Facilities," Code of Federal Regulations. Available at:

http://ecfr.gpoaccess.gov/cgi/t/text/textidx?c=ecfr\&sid=b82e7384296a8862ac89f0477bac61d4\&rgn=div6\&view=text\&node=40:8.0. 1.1.1.8\&idno $=40$.

CAP-88 PC, Clean Air Act Assessment Package-1988, Version 2.0, U.S. Environmental Protection Agency National Computer Center, Research Triangle Park, North Carolina. Available at: http://www.epa.gov/radiation/assessment/CAP88/\#version20.

Clean Air Act of 1990, 42 USC 7401, et seq. Available at: http:/www.epa.gov/air/caa/.

DOE/RL-2006-29, 2006, Calculating Potential-to-Emit Radiological Releases and Doses, Rev. 0, U.S. Department of Energy, Richland Operations Office, Richland, Washington. Available at: http://www5.hanford.gov/arpir/?content=findpage\&AKey $=0904290337$.

DOE/RL-2007-56, 2008, Deep Vadose Zone Treatability Test Plan for the Hanford Central Plateau, Rev. 0, U.S. Department of Energy, Richland Operations Office, Richland, Washington. Available at: $\underline{\mathrm{http}} \mathrm{/} / \mathrm{www}$ 5.hanford.gov/arpir/?content=findpage\&AKey=0804160110.

DOE/RL-2009-119, 2009, Characterization of the Soil Desiccation Pilot Test Site, Draft A,

U.S. Department of Energy, Richland Operations Office, Richland, Washington. Available at: http://www5.hanford.gov/arpir/?content=findpage \&AKey $=0084573$.

Lenntech, relative humidity calculator. Available at:

http://www.lenntech.com/calculators/relative-humidity.htm.

RCW 70.94, "Public Health and Safety," "Washington Clean Air Act," Revised Code of Washington, Washington State, Olympia, Washington. Available at: http://apps.leg.wa.gov/RCW/default.aspx?cite=70.94.

WAC 173-400, "General Regulations for Air Pollution Sources," Washington Administrative Code, Olympia, Washington. Available at: http://apps.leg.wa.gov/WAC/default.aspx?cite=173-400.

400-035, "Portable and Temporary Sources."

400-040, "General Standards for Maximum Emissions." 
WAC 173-460, "Controls for New Sources of Toxic Air Pollutants," Washington Administrative Code, Olympia, Washington. Available at: http://apps.leg.wa.gov/WAC/default.aspx?cite=173-460.

460-060, "Control Technology Requirements."

WAC 173-480, “Ambient Air Quality Standards and Emission Limits for Radionuclides," Washington Administrative Code, Olympia, Washington. Available at:

http://apps.leg.wa.gov/WAC/default.aspx?cite=173-480.

WAC 246-247, "Radiation Protection-Air Emissions," Washington Administrative Code, Olympia, Washington. Available at: http://apps.leg.wa.gov/WAC/default.aspx?cite=246-247.

247-040, "General Standards." 
SGW-47024, REV. 0 


\section{Distribution}

$\underline{\text { MS }}$

Quantity

\section{U.S. Department of Energy, Richland Operations Office}

DOE Public Reading Room

H2-53

1

CH2M HILL Plateau Remediation Company

J. A. Bates

H8-45

1

M. W. Benecke

R3-60

1

B. J. Dixon

H8-45

1

N. A. Homan

H8-45

1

R. W. Oldham

R3-60 1

C. J. Perkins

H7-28 1

F. M. Simmons

H8-45

1

G. B. Chronister

R3-60

1

Publications Technical Library

H3-21

1

Administrative Record

H6-08

1

Document Clearance

H6-08

1 
SGW-47024, REV. 0

Distr-2 